\title{
Revista Brasileira de Geografia Física
}

\section{Cereus jamacaru DC. and Pilosocereus pachycladus F. Ritter (Cactaceae) in the Northeast region of Brazil: future perspectives and distribution ${ }^{1}$}

Thamires Kelly Nunes Carvalho. Doctor in Development and Environment. Laboratory of Ethnobiology and Environmental Sciences. Federal University of Paraíba, Campus I, João Pessoa, Paraíba. e-mail: carvalhotkn@gmail.com (Correspondig autlhor);

José Ribamar Farias Lima. Doctor in Development and Environment. Laboratory of Ethnobiology and Environmental

Sciences. Federal University of Paraíba, Campus I, João Pessoa, Paraíba. e-mail: ribamarfl@ gmail.com;

Ramon Santos Souza. Master in Geography (PPGG). Federal University of Paraíba, Campus I, João Pessoa, Paraíba. email: ramonssouza@gmail.com;

João Everthon da Silva Ribeiro Doctor in Agronomy. Federal University of Paraíba, Campus II, Sand, Paraíba. e-mail: j.everthon@hotmail.com;

Ezequiel da Costa Ferreira. Doctoral Student of the Graduate Program in Development and Environment. Laboratory of Ethnobiology and Environmental Sciences. Federal University of Paraíba, Campus I, João Pessoa, Paraíba. e-mail: ezequielcostaf@gmail.com;

Denise Dias da Cruz. Professor of the Graduate Program in Development and Environment - PRODEMA. Terrestrial Ecology Laboratory, Department of Systematics and Ecology, Center for Exact and Natural Sciences, Federal University of Paraíba, João Pessoa, Paraíba. e-mail: denidcruz@dse.ufpb.br;

Reinaldo Farias Paiva de Lucena Professor of the Graduate Program in Development and Environment - PRODEMA. Coordinator of the Laboratory of Ethnobiology and Environmental Sciences, Department of Systematics and Ecology, Center for Exact and Natural Sciences. Federal University of Paraíba, João Pessoa, Paraíba.e-mail: rlucena@dse.ufpb.br.

Artigo recebido em 05/05/2020 e aceito em 14/12/2020

\begin{abstract}
A B S T R A C T
The Caatinga covers $912,529 \mathrm{~km}^{2}$ throughout most of the Northeast region of Brazil and accounts for 28.6 million people. This region is characterized by high aridity and long drought periods. In 2013, the International Panel on Climate Change (IPCC) warned that tropical regions, including the semi-arid region of Brazil (mostly covered by Caatinga), will be affected by global climate change. Species of ecological and socio-cultural importance may be impacted by climate change, culminating in a local vulnerability scenario. Our goal was to elaborate maps to predict the future distribution of Cereus jamacaru DC. Subsp. Jamacaru and Pilosocereus pachycladus F. Ritter subsp. Pernambucoensis (F. Ritter) Zappi as a function of climatic changes. The results indicate that C. jamacaru will increase its istribution in 2050 (in the RCP8.5 scenario) while $P$. pachycladus will decrease in suitable habitat These findings reaffirm the prediction of desertification in the Caatinga. The interrelationship between man and the studied species, as plant resources, should also be considered to evaluate the social impact and vulnerability conditions of populations that depend on plant resources. Keywords: Climate change, Cactaceae, Semi-arid Brazil, Caatinga.
\end{abstract}

\section{Cereus jamacaru DC. E Pilosocereus pachycladus F. Ritter (Cactaceae) na região Nordeste do Brasil: perspectivas e distribuição futuras}

\section{R E S U M O}

A Caatinga ocupa $912.529 \mathrm{~km}^{2}$ abrangendo grande parte da região nordeste do Brasil onde habitam 28,6 milhões de pessoas. Esta região é caracterizada por altas temperaturas e longos períodos de seca. Em 2013, o Painel Internacional sobre Mudanças Climáticas (IPCC) alertou que as regiões tropicais, incluindo a região semiárida do Brasil (principalmente a parte coberta pela Caatinga), serão afetadas pelas mudanças climáticas globais. Espécies de importância ecológica e sociocultural podem ser impactadas pelas mudanças climáticas, culminando em um cenário de vulnerabilidade local. Nosso objetivo foi elaborar mapas para prever a distribuição futura de Cereus jamacaru DC. subsp. jamacaru e Pilosocereus pachycladus F. Ritter subsp. pernambucoensis (F. Ritter) Zappi em função das mudanças climáticas. Os resultados indicam que $C$. jamacaru aumentará sua distribuição em 2050 (no cenário RCP8.5) enquanto diminuirá habitat

\footnotetext{
${ }^{1}$ Trabalho extraído da Dissertação de Mestrado da primeira autora. Projeto financiado pela CAPES.
} 
adequado para P. pachycladus. Esses achados reafirmam a previsão de desertificação na Caatinga. A inter-relação entre o homem e as espécies estudadas, como recursos vegetais, também deve ser considerada para avaliar o impacto social e as condições de vulnerabilidade das populações que dependem dos recursos vegetais.

Palavras-chave: Mudanças climáticas, Cactaceae, Semiárido do Brasil, Caatinga.

\section{Introduction}

The Caatinga covers most of the semi-arid region of Brazil. It occupies $80 \%$ of the Northeast Region and a small area in the Central-West Region (in Minas Gerais), an area that encompasses nine states. It has low annual average rainfall, high aridity indices, and the frequent occurrence of long drought periods, with rainy months from January to April and no rain from May to December ( Prado, 2003; Moura et al., 2007). In Brazil, this region accounts for more than 28.6 million people who are distributed over $912,529 \mathrm{~km}^{2}$ (Silva, 2011).

Low-tech agriculture, the main source of income for the majority of the population, combined with the dependence on natural resources due to the extreme climate, results in a scenario of socioeconomic vulnerability (Angelotti et al., 2011). A system is considered vulnerable when it is susceptible to climate events/changes, due to physical or social factors, and demonstrates an inability to adapt to the consequences of these changes (Adger et al., 2003). Understanding this concept is essential to interpret the impact of climate change on human populations (Adger and Kelly, 1999).

A report, published in 2013 (The Physical Science Basis) by the International Panel on Climate Change (IPCC), warned that tropical regions, including the semi-arid region of Brazil, will be affected by global climate change, with a consequent increase in temperature and a shorter time interval between drought periods, which will directly affect water resources (IPCC, 2013). Climate change directly affects the physiological dynamics and ability of plant species to remain in affected areas. Changes in atmospheric patterns on a large scale may increase the demand for evapotranspiration (Souza et al., 2015), which would cause water stress in plant species. This situation was recorded throughout the Atlantic Dipole phenomenon in the Caatinga in 2012 which prolonged the period of low precipitation (Gutiérrez et al., 2014). In this context, species distribution models based on climate change are widely used and may help to predict possible impacts on species distribution in areas exposed to climate change (Peterson et al., 2002; Thuiller, 2004; Araújo et al., 2006; Pearson et al., 2006; Thuiller et al., 2009).
Spatial distribution modeling has become common for two reasons: (1) access and advancement in statistical methods and instruments, which may use field surveys as well as data from museums and herbariums, and (2) the availability of environmental data at levels that can reproduce the distribution in any area of the world, making it possible to work on a global scale (Marco Júnior and Siqueira, 2009).

In the case of the Caatinga, distribution studies focused on specific botanical families, including Cactaceae, already attempted to relate their distribution to species diversity (Menezes et al., 2013) as well as altitudinal variation and nearby inhabited residences, such as precursor studies on domestication (Lucena et al., 2015a). These studies consider the ecological, cultural, and economic importance of this botanical family within the biome; however, studies that deal with the climatic factor and its influence on the distribution of species are still needed. From this perspective, Cactaceae is a highly representative botanical family in Northeast Brazil (Castro, 2008; Silva et al., 2017), because it has specific morphophysiological characteristics such as photosynthetic stems with a thick cuticle, no leaves, mucilaginous tissue, and water saving in processes used to obtain energy (Terrazas and Mauseth, 2002); it is well adapted to semi-arid environments. Thus, it became an abundant resource for diverse purposes, since it is available even in drought periods (Duque, 1980; Lucena et al., 2012, 2013, 2014, 2015b).

Lucena et al. (2015a) reported the importance of this family in a study performed in the state of Paraíba. They explained that the lack of native pasture combined with the water deficit leads small farmers to use native cacti species in an attempt to solve animal feed problems. This practice has been repeated for each drought cycle over the years (Duque, 2004; Cavalcanti Filho, 2010; Nunes et al., 2015).

Cereus jamacaru DC. subsp. jamacaru and Pilosocereus pachycladus F. Ritter subsp. pernambucoensis (F. Ritter) Zappi are the main species used as fodder in the semi-arid region of Brazil; they are columnar and tree-sized, widely found in this region, and used due to their utilitarian versatility and considerable numbers (Lucena et al., 2015a, 2015b; Dantas et al., 2017; Silva et al., 2019). Cactaceae species are important resources for use as fodder, food, in rural and domestic 
constructions, in folk medicine, and as energy sources (firewood). The possible preference of farmers for the use of native species, especially $C$. jamacaru and $P$. pachycladus, is due to drought periods and consequent lack of pasture for the herds (Carvalho, 2016).

In this context, the present research is based on the hypothesis that the prediction of a reduction in the regular intervals of drought regime, combined with temperature increase, will influence the availability and distribution of native cactus species that are primarily used as fodder resources in periods of scarcity. Thus, this study aimed to elaborate current prediction maps of future $C$. jamacaru and $P$. pachycladus distributions, as a function of climatic changes, and to relate fodder use dynamics to the drought regime in the Caatinga and identify the consequences of climate change on these species.

\section{Material and methods}

Areas with known $C$. jamacaru and $P$. pachycladus occurrence, obtained from the Global Biodiversity Information Facility - GBIF (https://www.gbif.org), were also used (through functions with the spocc and mapdata packages in $\mathrm{R}$ software) in order to search for occurrence data and clean duplicate points. This procedure aimed to obtain the distribution of both species in the Northeast region and resulted in 130 C. jamacaru and $98 \mathrm{P}$. pachycladus specimens. From the two data collection modes, we obtained $255 C$. jamacaru and $228 P$. pachycladus distribution points used in the analyses.

We used a modeling database that consisted of 19 bioclimatic variables (Hijmans et al., 2005) and a biophysics variable (elevation) with a spatial resolution of 30 seconds of arc (approximately 1 $\mathrm{km}^{2}$ ) obtained from the WorldClim dataset (www.worldclim.org). Current climate data correspond to the interpolated database from 1960 to 1990. Observations of the representative scenarios of carbon dioxide concentrations (RCPs), optimistic (RCP4.5) and pessimistic (RCP8.5), as derived from the HadGEM2-ES model, allow one to formulate a predictive niche model that demonstrates the possible distribution of the species by the year 2050 (average predictions for 2041-2060). These data were the most recent climate projections of the Global Circulation Models (GCMs) used in the fifth IPCC report (CMIP5).
To reduce multicollinearity, highly correlated variables (Pearson's correlation coefficient $r \geq$ 0.85) were excluded (Graham, 2003). This reduction resulted in the inclusion of 12 predictor variables: isothermalism (Bio3), seasonality of temperature (Bio4), maximum temperature of the hottest month (Bio5), minimum temperature of the coldest month (Bio6), annual thermal amplitude (Bio7), average temperature of the wettest term (3 months) (Bio8), average temperature of the coldest term (Bio11), annual precipitation (Bio12), precipitation in the driest month (Bio14), seasonality of precipitation (Bio15), precipitation in the hottest term (Bio18), and precipitation in the coldest term (Bio19).

We used R software for ecological niche modeling using the MaxEnt (Phillips et al., 2006) through the dismo package (Hijmans et al., 2017). This algorithm has worked better with small samples in comparison to other modeling methods (Kumar and Stohlgren, 2009; Pearson et al., 2007). In the models of the present study, $75 \%$ of data for training and $25 \%$ for testing the model (Phillips and Dudík, 2008) were selected using k-fold partitioning, and 10,000 random background points were created. The Jackknife test was performed to determine the importance of the variables (Figure 1). The area under the curve (AUC) or receive operating characteristic (ROC) curve was used to evaluate the performance of the model. The AUC value ranges from 0 to 1 (Fielding and Bell, 1997). An AUC value up to 0.50 indicates that the model did not perform better than a random model, whereas an AUC equal to 1.0 indicates perfect discrimination (Swets, 1988).

For exhibition and later analysis, predicting the presence of a species (0-1), the models were reclassified with QGIS 2.18 (QGIS Development Team, 2018), based on a classification reference proposed by Yang et al., (2013) in five potential classes: unsuitable habitat $(0-0.2)$; little suitable habitat $(0.2-0.4)$; suitable habitat (0.4-0.6); highly suitable habitat (0.6-0.8); very highly suitable habitat $(0.8-1.0)$ (Yang et al., 2013). The distribution area was calculated for each model, and binary values of presence (1) and absence $(0)$ were obtained by using a cut threshold that maximizes the sum between sensitivity (true positives) and specificity (true negatives) according to the test data (MaxSS) (JiménezValverde and Lobo, 2007; Liu et al., 2013). 

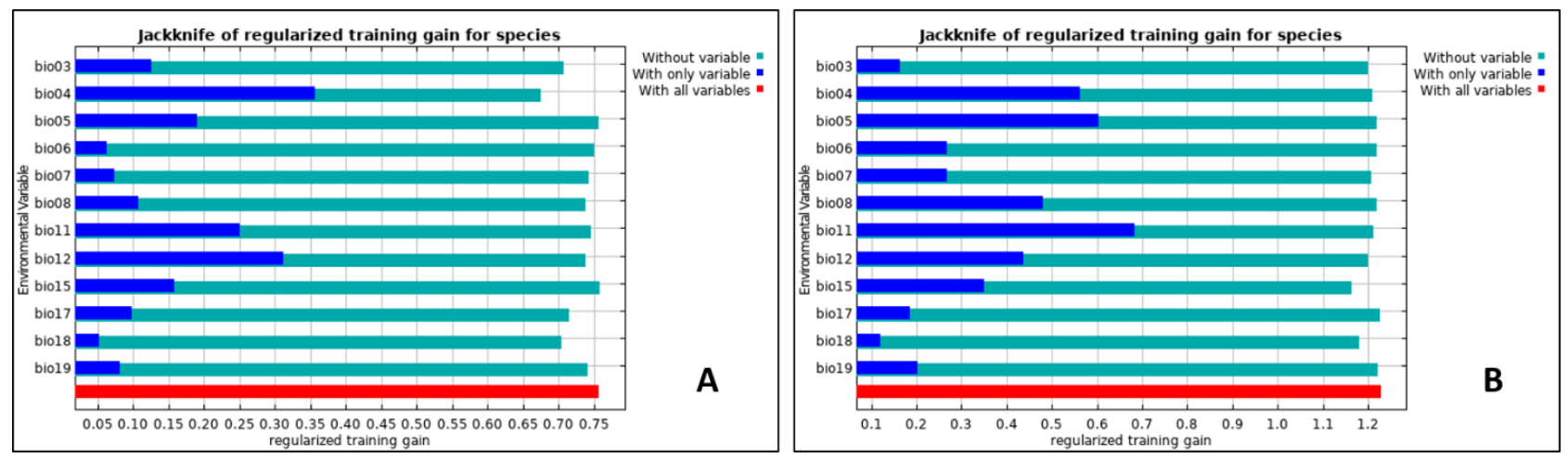

Figure 1: Evaluation of the relative importance of environmental variables by the Jackknife test. A and $\mathbf{B}$ show the results for $C$. jamacaru and $P$. pachycladus, respectively.

\section{Results}

The current occurrence data (Figure 2) indicated changes in the probable distribution of the two species for both RCP4.5 and RCP8.5. For C. jamacaru (Figure 3A), the probability of its occurrence increased as the temperature increased. Since the scenarios simulate a higher carbon concentration, this species could be distributed in all Northeast region states, especially Piauí and Maranhão. For P. pachycladus (Figure 3B), there was a substantial decrease in the distribution probability for the RCP8.5 scenario, especially in Rio Grande do Norte, Paraíba, Pernambuco and Alagoas states.

The future distribution modeling (Figure 3) showed, to the detriment of climatic variables, an increase in highly suitable habitat (0.6-0.8) and very highly suitable habitat $(0.8-1.0)$ to predict the presence of $C$. jamacaru (Figure 2A) in 2050, with a larger expansion in the RCP8.5 scenario. Conversely, there was an increase in unsuitable habitat $(0-0.2)$ and a decrease in suitable habitat for the prediction of $P$. pachycladus presence (Figure 3B).
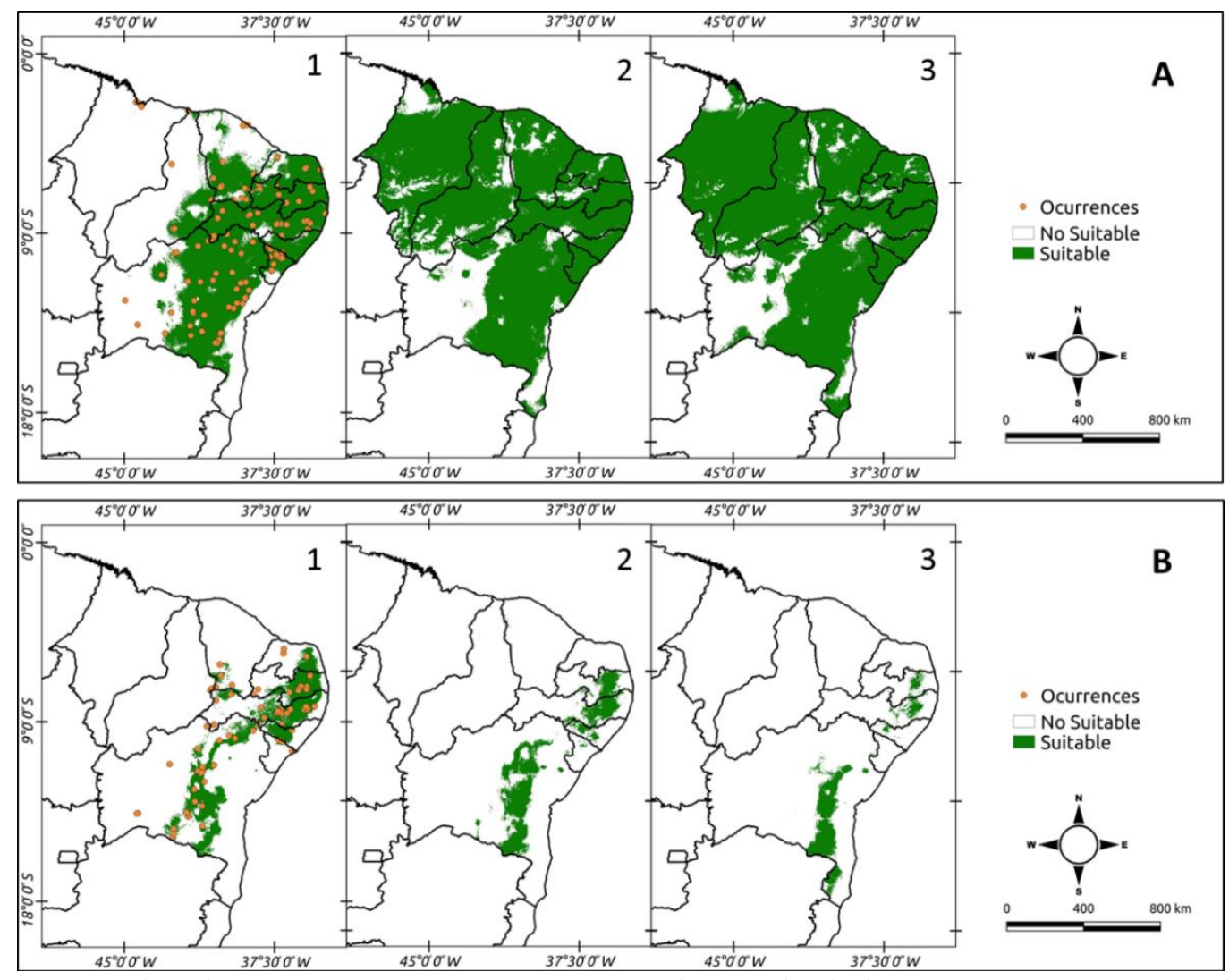

Figure 2: Current distribution map of C. jamacaru (A) and P. pachycladus (B). Notes: 1) species distribution points, 2) distribution according to the optimistic scenario (RCP4.5), and 3) distribution according to the pessimistic scenario (RCP8.5). 


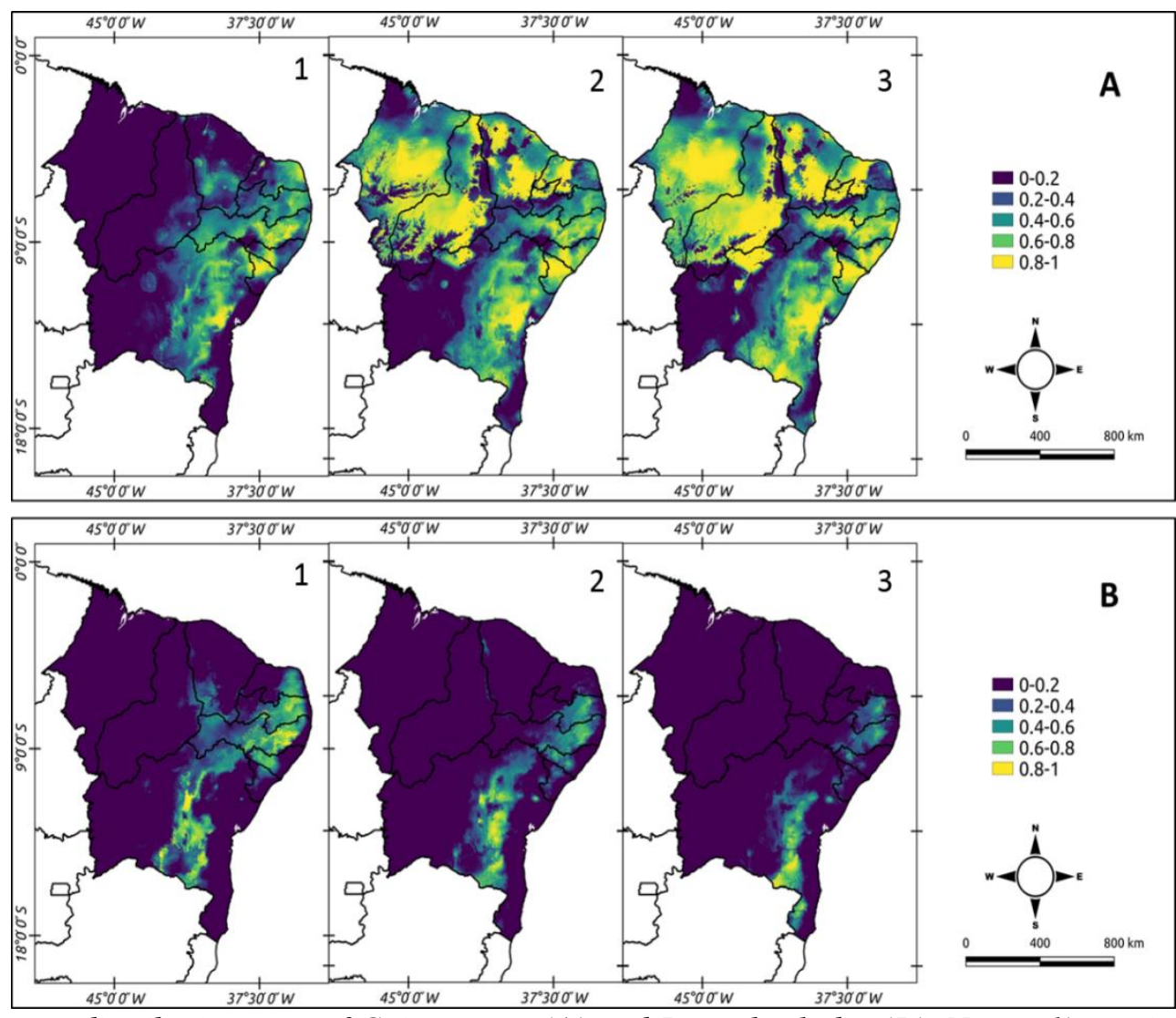

Figure 3: Future distribution map of C. jamacaru (A) and P. pachycladus (B). Notes: 1) species distribution points, 2) distribution according to the optimistic scenario (RCP4.5) and 3) distribution according to the pessimistic scenario (RCP8.5).

\section{Discussion}

The results from the predictive maps indicate a change in the distribution of the studied species, especially the expansion of areas with habitat favorable for $C$. jamacaru. This expansion may be related to the increase in areas undergoing desertification in the Caatinga biome. Future climate models and projections indicate a possible savannization in parts of the Amazon and intensification in the desertification process in the Caatinga as a consequence of the current global climate scenario (Torres et al., 2017). Such predictions would directly impact biodiversity, quality, and distribution of resources, as well as conditions for maintaining climate and life, such as water and carbon stocks.

The vulnerability to climatic variations of columnar cacti and other plants with a succulent stem may be explained as a relationship between the adaptive response of stem dimensions and precipitation variations in the environment where the plant is established (Williams et al., 2014). Therefore, when analyzing distribution data, the physiological characteristics of each species, and their ability to adapt to relevant climatic stress, should be examined. For this study, we considered that the climate abiotic factor will become the basis for future complementary studies that involve physiological and ecological aspects of the plants.

The semi-arid region of Brazil, according to global climate perspectives, will be one of the regions most affected by rainfall deficit and aridity increase (Marengo et al., 2017). These changes will directly impact human populations that live in this region and have an interrelationship with its natural resources. The social and cultural importance of the species under study result from this relationship between people and plant resources in the Caatinga. The use of $C$. jamacaru and $P$. pachycladus is one of the only alternatives for animal feed during drought periods in Paraiba communities (Lucena et al., 2015a).

Moreover, different review studies (Santos et al., 2017; Silva et al., 2019) that list documented uses of Cactaceae species, specifically $C$. jamacaru, emphasize the importance of its use by local populations in all northeastern states of Brazil and show that most of these uses are related to the feed security of herds during water scarcity periods. Silva et al. (2019) point out that it is necessary to invest in studies aimed at optimizing and prospecting the fodder potential of this species.

It is understood that climate change and its consequences directly affect the way of life of millions of people who live in the semi-arid region 
of Brazil. This directly impacts how these people relate to the environment and how they extract or conserve the natural resources essential for their survival. Thus, further studies on the use, management and conservation of Cactaceae should be carried out.

Therefore, the potential changes in $C$. jamacaru and $P$. pachycladus distributions may influence the dynamics of their use, local knowledge, and management by traditional populations. Thus, anthropogenic disturbance, which directly contributes to shortening natural climate cycles and consequent rapid advance in climate change worldwide (Torres et al., 2017), should be included in a complementary manner when interpreting data and climate prediction models, not only for causing degradation but as one of the factors for understanding the level of exposure and vulnerability of the ecosystem to these events.

There are some important and relevant questions for future scenarios: (1) Will the extraction and management of $C$. jamacaru and $P$. pachycladus be influenced by the increase/decrease in their availability or by the extreme climatic conditions? (2) Can these dynamics influence or trigger species domestication processes? (3) What are the ecological and cultural consequences of this new scenario? (4) What is the degree of socio-climatic vulnerability of these human populations to the detriment of the environmental changes that will occur?

Some of these answers have been sought in several regions of the world. Butt and Gallagher (2018) evaluate the vulnerability of plant species, considering their ability to adapt to climate change. Chombo et al. (2018) present an alternative for researchers who wishes to analyze the climate vulnerability of human populations in small regions. These studies may be theoretical instruments to be applied in the Northeast region of Brazil.

Ethnoscience studies direct the understanding of the relationship between the people and the environment, the use and management of species. The domestication process is closely linked to the use of morphological variability (Casas et al., 2016). Considering the importance of the documented Cactaceae columnar species, especially $C$. jamacaru, and the possible advance in the distribution, as well as the increased availability, it is essential to investigate how the dynamics of the relationship between local populations and this species will occur and the ecological and sociocultural characteristics of this interaction.
Some studies indicate it is still impossible to clearly state how Caatingan species will behave in the face of this new climatic scenario (Marengo et al., 2009; Marengo et al., 2017). Nevertheless, efforts in research should be allied with government initiatives that reduce poverty (and thus the dependence of rural populations on plant resources) while also aiming to reduce the pressure on native areas (Santos et al., 2014).

\section{Final considerations}

The data presented in this study indicate that the distribution and prediction of the occurrence of $C$. jamacaru and P. pachycladus will undergo changes in an extreme climate change scenario, a finding that reaffirms the predictions of desertification in the Caatinga.

The data obtained as a function of climatic variations (an abiotic factor) may contribute to indepth studies involving the physiological adaptation capacity of species to climatic stress, as well as for the development of biodiversity management and conservation plans.

Plant resource extractions, as well as the interrelationship between man and the studied species, as plant resources, should also be considered to evaluate the social impact and vulnerability of the populations that depend on the resources, of which distribution will be altered over the years due to detrimental climate changes.

\section{References}

Adger, W.N., Huq, S., Brown, K., Conway, D., Hulme, M., 2003. Adaptation to climate change in the developing world. Progress in Development Studies 3, 179-195.

Adger, W.N., Kelly, P.M., 1999. Social vulnerability to climate change and the architecture of entitlements. Mitigation and Adaptation Strategies for Global Change 4, 253-266.

Angelotti, F., Fernandes Júnior, P.I., Sá, I.B., 2011. Mudanças Climáticas no Semiárido Brasileiro: Medidas de Mitigação e Adaptação. Revista Brasileira de Geografia Física, 4, 1097-1111.

Araújo, M.B., Thuiller, W., Pearson, R.G., 2006. Climate warming and the decline of amphibians and reptiles in Europe. Journal of Biogeography, 33, 1712-1728.

Butt, N., Gallagher, R., 2018. Using species traits to guide conservation actions under climate change. Climatic Change, 151, 317-332.

Carvalho, T.K.N., 2016. Conhecimento Botânico Local sobre Cactáceas no Semiárido da 
Paraíba, Nordeste do Brasil. Dissertação (Mestrado). João Pessoa, UFPB.

Casas, A., Torres-Guevara, J., Parra, F., Cruz, A., 2016. Domesticación y agricultura en América: historia y perspectivas del manejo de recursos genéticos en el Nuevo Mundo, in: Casas, A., Torres-Guevara, J., Parra, F., (Eds.), Domesticación en el continente americano, Volumen 1: Manejo de biodiversidad y evolución dirigida por las culturas del Nuevo Mundo, Universidad Nacional Autónoma de México y Universidad Nacional Agraria La Molina, México; Lima:, pp. 13-23.

Castro, J.P., 2008. Número cromossômicos em espécies de Cactaceae ocorrentes no Nordeste do Brasil. Dissertação (Mestrado). Areia, UFPB.

Cavalcanti Filho, J.R.C., 2010. A água como elo de identidades sociais no semi-árido paraibano: estudo de caso, Cabaceiras. Dissertação (Mestrado) - Araraquara, Centro Universitário de Araraquara.

Chombo, O., Lwasa, S., Makooma, T.M., 2018. Spatial Differentiation of Small Holder Farmers' Vulnerability to Climate Change in the Kyoga Plains of Uganda. American Journal of Climate Change, 07, 624-648.

Duque, J.G., 1980. O Nordeste e as lavouras xerófilas, 3 ed. Coleção Mossoroense, Mossoró.

Duque, J.G., 2004. O Nordeste e as lavouras xerófilas, 4 ed. Banco do Nordeste do Brasil, Fortaleza.

Fielding, A H., Bell, J.F., 1997. A review of methods for the assessment of prediction errors in conservation presence/absence models. Environmental Conservation, 24, $38-49$.

Graham, M.H., 2003. Confronting Multicollinearity in Ecological Multiple Regression. Source: Ecology, 84.

Gutiérrez, A.P.A., Engle, N.L., Nys, E., Molejón, C., Martins, E.S., 2014. Drought preparedness in Brazil. Weather and Climate Extremes, 3, 95-106.

Hijmans, R.J., Cameron, S.E., Parra, J.L., Jones, P.G., Jarvis, A., 2005. Very high resolution interpolated climate surfaces for global land areas. International Journal of Climatology, 25, 1965-1978.

Hijmans, R.J., Philips, S., Leathwick, J., Elith, J., 2017. dismo: Species distribution modeling. $\mathrm{R}$ package version 1.1-4. Dismo: Species Distribution Modeling. R Package Version 1.1-4. Retrieved from https://cran.rproject.org/package=dismo
IPCC, 2013. Summary for Policymakers, in Stocker, T.F., Qin, D., Plattner, G.-K., Tignor, M., Allen, S.K., Boschung, J., Nauels, A., Xia, Y., Bex, V., Midgley, P.M., (Eds.), Climate Change 2013: The Physical Science Basis. Contribution of Working Group I to the Fifth Assessment Report of the Intergovernmental Panel on Climate Change. Cambridge University Press Cambridge and New York, pp. 3-29.

Jiménez-Valverde, A., Lobo, J.M., 2007. Threshold criteria for conversion of probability of species presence to either-or presence-absence. Acta Oecologica 31, 361369.

Kumar, S., Stohlgren, T.J., 2009. Maxent modeling for predicting suitable habitat for threatened and endangered tree Canacomyrica monticola in New Caledonia. Journal of Ecology and Natural Environment (Vol. 1). Retrieved from

http://www.academicjournals.org/JENE

Liu, C., White, M., Newell, G., 2013. Selecting thresholds for the prediction of species occurrence with presence-only data. Journal of Biogeography 40, 778-789.

Lucena, C.M., Carvalho, T.K.N., Marín, E.A., Nunes, E.N., Oliveira, R.S., Melo, J.G., Casas, A., Lucena, R.F.P., 2014. Potencial medicinal de cactáceas en la región semiárida del Nordeste de Brasil. Gaia Scientia Especial, 36-50.

Lucena, C.M., Carvalho, T.K.N., Ribeiro, J.E.S., Quirino, Z.G.M., Casas, A., Lucena, R.F.P., 2015a. Conhecimento botânico tradicional sobre cactáceas no semiárido do Brasil. Gaia Scientia 9, 77-90.

Lucena, C.M., Costa, G.M., Sousa, R.F., Carvalho, T.K.N., Marreiros, N.A., Alves, C.A.B., Pereira, D.D., Lucena, R.F.P. 2012. Conhecimento local sobre cactáceas em comunidades rurais na mesorregião do sertão da Paraíba (Nordeste, Brasil). Biotemas 25, 281-291.

Lucena, C.M., Lucena, R.F.P., Costa, G.M., Carvalho, T.K.N., Costa, G.G.S., Alves, R.R.N., Pereira, D.D., Ribeiro, J.E.S., Alves, C.A.B., Quirino, Z.G.M., Nunes, E.N., 2013. Use and knowledge of Cactaceae in Northeastern Brazil. Journal of Ethnobiology and Ethnomedicine [online] 9. Avaliable: https://www.ethnobiomed.com/content/9/1/6 2. Acessed: 09/12/2016

Lucena, C.M., Ribeiro, J.E.S., Nunes, E.N., Meiado, M.V., Quirino, Z.G.M., Casas, A., Lucena, R.F.P., 2015b. Distribuição local de Cereus jamacaru DC. subsp. jamacaru e 
Pilosocereus pachycladus F Ritter subsp. pernambucoensis (F. Ritter) Zappi (Cactaceae) e sua relação com uma comunidade rural no Município do Congo, Paraíba. Gaia Scientia 9, 97-103.

Marco Júnior, P., Siqueira, M. F., 2009. Como determinar a distribuição potencial de espécies sob uma abordagem conservacionista? Megadiversidade, 5, 6574.

Marengo, J.A., Jones, R., Alves, L.M., Valverde, M.C., 2009. Future change of temperature and precipitation extremes in South America as derived from the PRECIS regional climate modeling system. International Journal of Climatology 29, 2241-2255.

Marengo, J.A., Torres, R.R., Alves, L.M., Drought in Northeast Brazil-past, present, and future. Theoretical and Applied Climatology, 129, 1189-1200.

Menezes, M.O.T., Taylor, N.P., Loiola, M.I.B., 2013. Flora do Ceará, Brasil: Cactaceae. Rodriguesia, 64, 757-774.

Moura, M.S.B., Galvincio, J.D., Brito, L.T.L., Souza, L.S.B., Sá, I.I.S., Silva, T.G.F., 2007. Semi-Árido, Clima e água de chuva no, in: Brito, L.T.L., Moura, M.S.B., Gama, G.F.B. (Eds.), Potencialidades da água de chuva no Semi-Árido brasileiro. Embrapa Semi-Árido, Petrolina, pp. 37-59.

Nunes, A.T., Lucena, R.F.P., Santos, M.V.F., Albuquerque, U.P., 2015. Local knowledge about fodder plants in the semi-arid region of Northeastern Brazil. Journal of Ethnobiology and Ethnomedicine [online] 11, Available: http://www.ethnobiomed.com/content/11/1/1 2. Acessed: 20/08/2017

Pearson, R.G., Raxworthy, C.J., Nakamura, M., Peterson, A.T., 2007. Predicting species distributions from small numbers of occurrence records: a test case using cryptic geckos in Madagascar. Journal of Biogeography $34,102-117$.

Pearson, R.G., Thuiller, W., Araújo, M.B., Martinez-Meyer, E., Brotons, L., McClean, C., Miles, L., Segurado P., Dawson, T.P., Lees, D.C., 2006. Model-based uncertainty in species range prediction. Journal of Biogeography 33, 1704-1711.

Peterson, A.T., Ortega-Huerta, M.A., Bartley, J., Sánchez-Cordero, V., Soberón, J., Buddemeler, R.H., Stockwell, D.R.B., 2002. Future projections for Mexican faunas under global climate change scenarios. Nature 416, 626-629.

Phillips, S.J., Anderson, R.P., Schapire, R.E., 2006. Maximum entropy modeling of species geographic distributions. Ecological Modelling, 190, 231-259.

Phillips, S.J., Dudík, M., 2008. Modeling of species distributions with Maxent: new extensions and a comprehensive evaluation. Ecography, 31, 161-175.

Prado, D.E., 2003. As Caatingas da América do Sul, in: Leal, I.R., Tabarelli, M., Silva, J.M. (Eds.), Ecologia e conservação da Caatinga. Editora Universitária da UFPE, Recife, pp. 374.

QGIS Development Team., 2018. QGIS Development Team. Retrieved from http://qgis.osgeo.org

Santos, C.A.G., Dantas, M.K.M., Medeiros, M.F. T., 2017. Reports of knowledge ad the uses of Cacataceae species in the Historia Naturalis Brasiliae (1648): Comparative Analyses. Ethnoscientia [online], 2. Available: https://doi.org/10.22276/ethnoscientia.v2i1.4 3. Acessed: 22 jul. 2018.

Santos, M.G., Oliveira, M.T., Figueiredo, K.V., Falcão, H.M., Arruda, E.C.P., AlmeidaCortez, J., Sampaio, E.V.S.B., Ometto, J.P. H.B., Menezes, R.S.C., Oliveira, A.F.M., Pompelli, M.F., Antonino, A.C.D., 2014. Caatinga, the Brazilian dry tropical forest: Can it tolerate climate changes? Theoretical and Experimental Plant Physiology 26, 8399.

Silva, J.M.C., Leal, I.R., Tabarelli, M., 2017. Caatinga - The Largest Tropical Dry Forest Region in South America. Springer, Gewerbestrasse

Silva, L.F.C.R., Valle, L.S., Nascimento, A.R.C., Medeiros, M.F.T., 2019. Cereus jamacaru DC. (cactaceae): From 17th century naturalists to modern day scientific and technological prospecting. Acta Botanica Brasilica 33, 191-197.

Silva, L.M.A., 2011. A relação entre peixes e habitat: métodos de análises. Estação Científica (UNIFAP) 1, 17-29.

Souza, L.S.B., Moura, M.S.B., Sediyama, G.C., Silva, T.G.F., 2015. Balanço de energia e controle biofísico da evapotranspiração na Caatinga em condições de seca intensa, Pesquisa Agropecuária Brasileira 50, 627636.

Swets, J.A., 1988. Measuring the accuracy of diagnostic systems. Science 240, 1285-1293.

Terrazas, T., Mauseth, J.D., 2002. Stem anatomy and morphology, in: Nobel, P. S. (Ed.), The cacti: biology and uses. University Press, Berkeley, pp. 47-60.

Thuiller, W., 2004. Patterns and uncertainties of species' range shifts under climate change. 
Global Change Biology 10, 2020-2027.

Thuiller,W., Lafourcade, B., Engler, R., Araújo, M.B., 2009. BIOMOD - a platform for ensemble forecasting of species distributions. Ecography 32, 369-373.

Torres, R.R., Lapola, D.M., Gamarra, N.L.R., 2017. Future climate change in the caatinga, in: Silva, J.M.C., Leal, I.R., Tabarelli, M. (Eds.), Caatinga: The Largest Tropical dry forest region in South America. Springer, Gewerbestrasse, pp. 383-410.
Williams, D.G., Hultine, K.R., Dettman, D.L., 2014. Functional trade-offs in succulent stems predict responses to climate change in columnar cacti. Journal of Experimental Botany 65, 3405-3413.

Yang, X.Q., Kushwaha, S.P.S., Saran, S., Xu, J., Roy, P.S., 2013. Maxent modeling for predicting the potential distribution of medicinal plant, Justicia adhatoda L. in Lesser Himalayan foothills. Ecological Engineering 51, 83-87. 